8. Леонтьев А. Н. Психологические механизмы мотивации учебной деятельности / Алексей Николаевич Леонтьев. - Новосибирск : НГПИ, 1987. - 92 с. 9. Маркова А. К. Формирование мотивации учения : [книга для учит.] / А. К. Маркова, Т. А. Матис, А. Б. Орлов. - М. : Просвещение, $1990 . \quad$ - 192 с. 10. Матюхина М. В. Мотивы учения учащихся с разным уровнем успеваемости / М. В. Матюхина // Мотивация учения. - Волгоград, 1976. - С. 5-15. 11. Рубинштейн С. Л. Человек и мир / С. Л. Рубинштейн // Методологические и теоретические проблемы психологии. - М., 1969. - С. 348-374. 12. Селиванов В. И. О побудительных силах поведения личности / В. И. Селиванов // Вопросы психологии. - М., 1957. - №3. - С. 106-113. 13. Хасанбаева Д. Х. Когнитивные механизмы формирования речевых действий : автореф. дисс. на соискание ученой степени канд. психол. наук : спец. 19.00.01 «Общая психология, история психологии»/ Д. Х. Хасанбаева. - Новосибирск, 1995. - 18 с. 14. Якобсон П. М. Психологические проблемы мотивации поведения человека / П. М. Якобсон. - М., 1969. - 317 с.

УДК 378.14:504-057.4

В. П. Строкаль, аспірант, Національний університет біоресурсів і природокористування Украӥни

\title{
ПРОФЕСІЙНО-ПРАКТИЧНЕ НАВЧАННЯ СТУДЕНТІВ У СТРУКТУРІ ЕКОЛОГІЧНОЇ ОСВІТИ
}

У роботі представлено етапи формування професійно-практичної підготовки майбутніх екологів ОКР «Бакалавр», обтрунтовано роль професійно-практичного навчання у структурі екологічної освіти.

Ключові слова: професійно-практична підготовка, екологічна освіта.

В работе представлены этапы формирования профессиональнопрактической подготовки будущих экологов ОКР «Бакалавр», обоснована роль профессионально-практического обучения в структуре экологического образования.

Ключевые слова: профессионально-практическая подготовка, экологическое образование.

This study illustrates phases of forming professional-practical study of the future Bachelor students - environmentalists. Main roles of the practical study in the environmental education have been established and discussed.

Key words: professional-practical study, environmental education.

Економіку держави спроможні підняти тільки виробники та висококваліфікований персонал, що мають достатньо ви- 
сокий науково-практичний потенціал, володіють новими технологіями, запасом життєвої активності й бажанням працювати. Адже поповнення бюджету, і підвищення рівня життя загалом настане за роботи товаровиробника. Ефективність роботи товаровиробника можуть підвищити тільки викокваліфіковані кадри - випускники вищих ВНЗ, які здобули високу професійно-практичну підготовку, володіють сучасними технологіями, мають активну життєву позицію. Тому пріоритетів розвитку вищої освіти постає удосконалення професійно-практичного навчання майбутніх фахівців. У зв'язку з постійними змінами ринку праці, окреслена проблематика набуває важливого значення вимагає удосконалення професійно-практичного навчання майбутніх фахівців через оволодіння ними знаннями, уміннями та навичками під час засвоєння теорії, методології та практики. Тому актуальність теми зумовлена тим нагальною потребою у формуванні професійнопрактичного навчання майбутніх фахівців.

I. Зимня [1] вивчала складові професійної компетентності сучасного фахівця, вважаючи, що ключові компетенції $є$ результативно-цільовою основою компетентного підходу в освіті. І. Лебедєва [2] вважає, що компетентність - це здатність діяти в ситуації невизначеності, здатність працювати в команді та навчатися. В. Введенський [3] розкриває питання моделювання професійної компетентності педагога. Н. Кузьміна [4] у працях розглядає професіоналізм особистості викладача й майстра виробничого навчання.

Питанням дидактики та проблем теорії та практики навчання займалися І. Шимко, І. Малафіїк, Н. Волкова, I. Шайдур та ін. І. Шимко [5] виокремила дидактичні умови, що можуть підвищити ефективність самостійної роботи студента: керівництво самостійною роботою, використання завдань проблемного характеру; врахування індивідуальних особливостей студента під час організації змісту навчальної роботи. Н. Волкова [6] та I. Малафіїк [7] розкрили зміст теоpiï та практики навчання, приділили увагу питанням, що стосуються діяльності, фахового розвитку, компетентності, комунікативної підготовки викладача та студента. Важливого значення в системі вищої освіти у процесі формування професійно-практичної компетенції належить науководослідним та практичним заняттям. Л. Довровська [10] виокремила чотири етапи організації науково-дослідної роботи студентів. І. Шайдур [8] розглядає індивідуальну самостійну 
роботу студента як змогу формування групи студентів за певними ознаками, наприклад, за успішністю чи працездатністю. Із упровадженням Болонського процесу у вищих навчальних закладах країни, I. Мороз [9] висуває вимоги до керівників самостійної роботи, наголошуючи на відкритості та загальній оглядовості завдань; обгрунтуванні необхідності завдань для стимулювання позитивних мотивів діяльності студентів; стандартизації та комплексності; наявності зворотнього зв’язку із студентами; інформаційності і технологічності.

Поміж науковців, які зробили вагомий внесок у розвиток екології як науки, можна виокремити: А. Наесса (глибинна екологія); Е. Уілсона і С. Келерта (принцип біофілії); Дж. Левлок (гіпотеза Геї); К. Майер-Абіха (парадигма спільно світу); М. Моїсєєва (концепції ко-еволюції, збалансованого розвитку); Т. Розака (концепт «екологічного несвідомого»), який уважає екологізм рухом, що охоплює соціальні й екологічні проблеми світу; Е. Блока (принцип надіі); Г. Йонаса (принцип відповідальності); Б. Нортона (екофілософія) та ін. Екологічна освіта стала передумовою започаткування освіти для сталого розвитку. Проблемам та ролі освіти в умовах сталого розвитку приділяли увагу науковці: В. Підліснюк, Л. Мельник, неперервності екологічної освіти, реформуванню національної науки і освіти - М. Дробноход, ступеневої екологічної освіти - Н. Рідей, освіті заради збалансованого розвитку - J. Smith, OOH, UNESCO, IUCN та ін. [13].

Здійснивши аналіз наукових досліджень та публікацій, дійшли висновку, що недостатньо приділено уваги дослідженню професійно-практичного навчання майбутніх фахівців, зокрема у структурі екологічної освіти. На нашу думку, це питання $€$ актуальним, оскільки визначає таку залежність чим успішнішою $є$ професійно-практична підготовка студента, тим більша його конкурентоспроможність на ринку освітніх послуг.

Mema cmammi - проаналізувати зміст професійнопрактичної підготовки студентів у структурі екологічної освіти. Для досягнення поставленої мети визначено такі завдання: з'ясувати етапи здійснення професійно-практичної підготовки майбутніх екологів, окреслити й обгрунтувати професійну підготовку майбутніх екологів у вищих аграрних навчальних закладах. 
Найважливішим чинником розвитку суспільства $є$ сприятливий екологічний стан. Екологічну освіту й науку започатковано в Київській Русі. Наші предки 3 давніх часів шанобливо ставилися до навколишнього середовища, з народження бережливо ставилась до матінки-землі й природи. Трипільна система й натуральне господарство дали початок розвитку різних ремесел, знання передавалися 3 покоління в покоління, збагачуючись досвідом. Саме на цьому підгрунті відбувається використання природних і кліматичних умов для вирощування високих врожаїв, розвитку тваринництва, розв'язання продовольчої проблеми, забезпечення низки галузей екологічно чистою сировиною. Розвиток освіти, особливо екологічної, тісно пов'язаний із проблемою «людинадовкілля». Нині екологічні проблеми набули статусу глобальних. Земля, що нас живить, повітря, яким ми дихаємо, вода, яку ми п'ємо, щорічно зазнають величезних втрат від необдуманої дії тих, хто ними користується. Покоління, що вступає в життя, одержало у спадщину екологічні проблеми, усвідомлення яких необхідне для світосприйняття. Тому в сучасному суспільстві постало питання підготовки висококваліфікованих фахівців екологічного спрямування.

Процес формування професійно-практичного навчання майбутніх екологів ОКР «Бакалавр» умовно можна поділити на кілька етапів (рис. 1):

- інформаційно-теоретичний: студенти одержують теоретичні знання, формують уміння, у них розвивається мотиваційна діяльність до навчання й обраної професії, вони визначають свій стиль та темп навчання, на практичних і семінарських заняттях закріплюють окремі теоретичні положення, обмінюються методичними знахідками, вчаться добирати методи й технології проведення занять теоретичного навчання;

- науково-практичний: студенти закріплюють одержані знання та вміння під час проходження навчальних практик, застосовують опановані технології, способи, форми та засоби екологічних досліджень, обгрунтовують загальну оцінку екологічного стану;

- науково-дослідницький: спрямований на закріплення студентами здобутих знань, умінь та навичок під час проходження науково-дослідницького практикуму та написання бакалаврської роботи; цей етап навчання, коли передбачає систематизацію знань. 


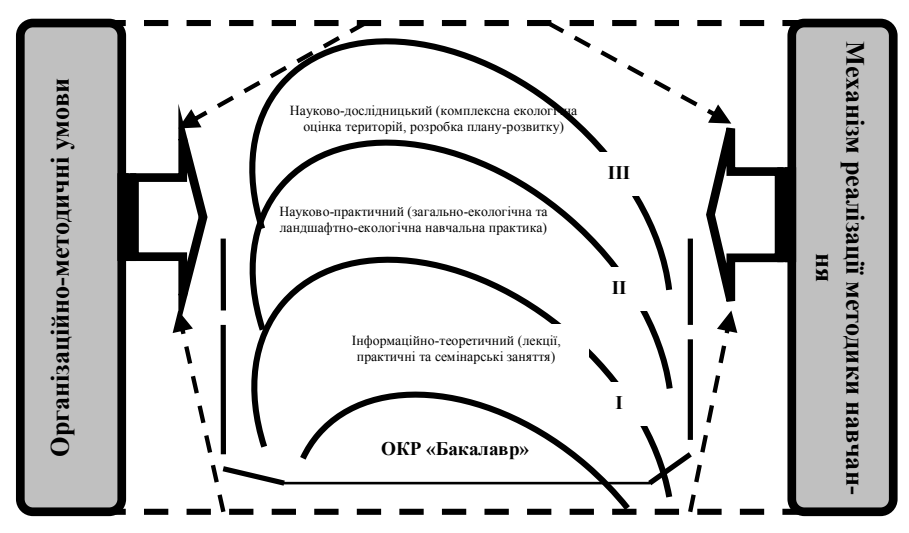

Рис. 1. Етапи формування професійно-практичної підготовки майбутніх екологів ОКР «Бакалавр»

На першому етапі (рис. 1) студенти-екологи одержують теоретичні, інформаційні, експериментальні, методичні знання у процесі засвоєння лекційних матеріалів (практичні та семінарські заняття).

Відповідно до навчального плану (базового) напрямку підготовки 6.040106 «Екологія, охорона навколишнього середовища та збалансоване природокористування» студентиекологи здобувають знання та вміння, вивчаючи такий цикл дисциплін: цикл гуманітарної та соціально-економічної підготовки, який складає $16 \%$ (5,7 кредитів) від загальної кількості годин теоретичної підготовки циклу; цикл природничонаукової підготовки - 20 \% (12 кредитів) циклу; цикл дисциплін професійної і практичної підготовки - 20 \% (14,6 кредитів) циклу; цикл дисциплін самостійного вибору ВНЗ, який складає 23 \% (13 кредитів) та цикл дисциплін вільного вибору студентом - $21 \%$ (4,3 кредити) теоретичної підготовки цього циклу.

На другому етапі - науково-практичному, студенти набувають навичок проведення науково-практичної роботи. Цей етап передбачає проходження навчальних практик, а також написання курсових робіт.

На третьому етапі студенти, які уже є фахівцями 3 певних питань досліджень, використовують набуті знання та вміння під час проходження науково-дослідницьких практикумів, таким чином формуючи навички самостійного написання та оформлення бакалаврської роботи. 
Навчальним планом (базовий) напрямку підготовки 6.040106 «Екологія, охорона навколишнього середовища та збалансоване природокористування» передбачено три блоки практик: I - загально-екологічна, яка включає навчальні практики із таких дисциплін: загальної екології; екології біологічних систем; геологія з основами геоморфології; грунтознавство; хімічний аналіз; інформатика і системологія; метеорологія і кліматологія; II - ландшафтно-екологічна, яка включає навчальні практики 3 таких дисциплін: топографія 3 основами картографії; радіобіологія і радіоекологія; основи сільськогосподарської екології; III - науково-дослідний практикум, що включає практики з циклу дисциплін за вибором студента: екологія агросфери; ландшафтна екологія; радіоекологія; гідроекологія; геоекологія; урбоекологія; біоекологія; екологічний менеджмент; екологічний туризм.

Залежно від екологічної ситуації, що склалася нині, а також від природно-кліматичних умов України зумовлено вибір вищих навчальних закладів у підготовці майбутніх фахівців в умовах різних екологічних ситуацій. Так, підготовку фахівців за спеціалізацією «Радіоекологія та радіаційна безпека» здійснюють Житомирський національний агроекологічний університет та Національний університет біоресурсів і природокористування України. Підготовку фахівців, які опікуюються збереженням біорізноманіття, природоохоронним режимом та заповідними територіями, здійснюють навчальні заклади в Рівненській, Львівській, Запорізькій та Київській областях - Національний університет біоресурсів і природокористування України, Львівський національний аграрний університет, Національний університет водного господарства та природокористування України, Таврійській державний агротехнологічний університет. Підготовку фахівців з гідроекології здійснюють у таких ВН3: Херсонському державному аграрному університеті, Національному університеті біоресурсів і природокористування України, Національному університеті водного господарства та природокористування України; планується - у Дніпропетровському державному аграрному університеті, Керченському державному морському технологічному університеті. Підготовку екологів у галузі «Екологія агросфери» здійснюють вищі навчальні заклади в різних регіонах України, зокрема Подільський державний аграрно-технічний університет, Львівській національний аграрний університет, Львівській національний університет 
ветеринарної медицини та біотехнологій ім. С. З. Гжицького, Житомирський національний агроекологічний університет, Білоцерківський національний аграрний університет, Луганський національний аграрний університет, Національний університет біоресурсів і природокористування України, Дніпропетровський державний аграрний університет.

Особливої уваги заслуговує екологічна освіта студентської молоді як основа формування майбутнього професіонала 3 високим почуттям обов'язку й відповідальності, здатного й готового обгрунтувати свою соціальну позицію, прийняти потрібне рішення й відповідно діяти в складній екологічній ситуації. Професійно-практичне навчання в екологічній освіті посідає одне з провідних місць, оскільки держава нині потребує кваліфікованих кадрів, які б мали високу професійнопрактичну підготовку, володіли сучасними інноваційними технологіями та мали активну життєву позицію.

\section{Література}

1. Зимняя И. А. Ключевые компетентности как результативноцелевая основа компетентностного подхода в образовании. Авторская версия / И. А. Зимняя. - М. : Исследовательский центр проблем качества подготовки специалистов, 2004. - 42 с. 2. Лебедев О. Е. Компетентностный подход в образовании [Электронный ресурс] / О. Е. Лебедев. - Режим доступа: www.nekrasovspb.ru

3. Введенский В. Н. Моделирование профессиональной компетентности педагога / В. Н. Введенский // Педагогика. - 2003. - № 10. С. 51-55. 4. Кузьмина Н. В. Профессионализм личности преподавателя и мастера производственного обучения / Н. В. Кузьмина. М. : Высшая школа, 1990. - 119 с. 5. Шимко І. М. Дидактичні умови організації самостійної навчальної роботи студентів ВНЗ / І. М. Шимко. - Кривий Ріг, 2003. - 20 с. б. Волкова Н. П. Педагогіка : [навч. посіб.] / Н. П. Волкова. - К. : Академвидав, 2009. - 616 с. 7. Малафіїк І. В. Дидактика : [навч. посібн.] / І. В. Малафіїк. - К. : Кондор. - 398 с. 8. Шайдур I. А. Організація самостійної роботи студентів педагогічних університетів на основі індивідуально орієнтованого підходу / І. А. Шайдур. - Полтава, 2003. - 15 с. 9. Мороз I. В. Педагогічні умови запровадження кредитномодульної системи організації навчального процесу : [монографія] / I. В. Мороз. - K. : ТОВ «Освіта України», 2005. - 23 с. 10. Домбровська Л. Організація самостійної та науководослідницької роботи / Л. Добровська // Освіта і управління. 2010. - Т. 13. - №2-3. - С. 189-196. 11. Типовий навчальний план за ОКР «Бакалавр», спеціальність «Екологія та охорона навколишнього природного середовища», НУБіП України. - 2008. 12. Основи загальної екології: програма навчальної дисципліни для підготовки 
фахівців в аграрних вищих закладах освіти із спеціальності «Екологія та охорона навколишнього природного середовища». К. : Аграрна освіта, 2008. 13. Рідей Н. М. Ступенева підготовка майбутніх екологів: теорія і практика : [монографія] / Н. М. Рідей / [за заг. ред. академіка Д. О. Мельничука]. - [2-ге вид.]. - Херсон : Вид-во «Олді-плюс», 2011. - 650 с.

\section{СПЕЦИФІКА ПРОФЕСІЙНОӤ ПІДГОТОВКИ МАЙБУТНЬОГО ПЕДАГОГА В КОНТЕКСТІ ЕСТЕТИЧНОГО ВИХОВАННЯ УЧНІВ ПОЧАТКОВИХ КЛАСІВ}

У статті розглянуто характерні особливості естетичного виховання молодших школярів та їх урахування під час підготовки вчителя до роботи з иією віковою категорією дітей.

Ключові слова: специфіка професійної підготовки, молодший школяр, естетичне виховання, підготовка вчителя.

В статье рассмотрены характерные особенности эстетического воспитания младших школьников, а также их влияние на подготовку учителя к работе с этой возрастной категорией детей.

Ключевые слова: специфика профессиональной подготовки, младший икольник, эстетическое воспитание, подготовка учителя.

The article describes the peculiarities of the aesthetic education in primary school and proves their influence on the elementary school teacher professional training in work with the pupils of this age category.

Key words: specific of the aesthetic education, primary school pupils, aesthetic education, teacher professional training.

Дитина перший раз переступить поріг школи, і тут все буде починатися $з$ учителя. Хоч дослідники відзначають, що кінцевий результат навчання та виховання залежить від трьох чинників: хто навчає, кого навчають і як навчають, у справі виховання роль учителя, його особистості є надзвичайно важливою.

Основи всебічного і гармонійного розвитку особистості започатковуються в дошкільнят, а початкова школа покликана продовжувати виконувати завдання складників виховної сфери. Жодному зі складників ми не надаємо перевагу, всі вони тісно між собою взаємозв'язані, доповнюють один од- 